\title{
TERMİK SANTRAL ÇALIŞANLARINDA İŞ YÜKÜ VE ZAMAN BASKISININ TÜKENMİŞLIKK ÜZERINNDEKİ ETKİSİ: İŞ - AİLE ÇATIŞMASINI YÖNETME ÖZ-YETERLIĞİNIN ARACILIK ETKİSİ
}

\author{
THE EFFECT OF WORKLOAD AND TIME PRESSURE ON BURNOUT \\ AMONG THERMAL POWER PLANT EMPLOYEES: MEDIATING ROLE \\ OF SELF-EFFICACY FOR MANAGING WORK-FAMILY CONFLICT
}

\section{Rahile GÜRAN ${ }^{* *}$ \\ Burcu KÜMBÜL GÜLER ${ }^{* * *}$}

\section{Öz}

Giderek ağırlaşan çalışma koşullarında çalışanlar kısıtlı zamanda yerine getirilmesi gereken birçok iş ve görev ile karşı karşıya kalmaktadır. Kısa zaman içinde yerine getirilmesi gereken iş çokluğu ve aile talepleri bireyin yaşamında zaman açısından çatışmalara neden olmaktadır. Bu araştırmanın amacı, işin nicel talepleri olan iş yükü ve zaman baskısının tükenmişlikle ilişkisinde iş ve aile çatışmasını yönetme öz-yeterliğinin aracılık etkisini incelemektir. Bu amaçla, termik santralde çalışan mavi yaka (işçi, usta, usta yardımcısı, ustabaşı, teknisyen, başteknisyen) ve beyaz yakalı (büro elemanı, mühendis, şef, müdür, uzman, yönetici) toplam 409 çalışana işin nicel talepleri, iş ve aile çatışması öz-yeterliği aracıllğ̆ ile tükenmişlik düzeylerini ölçmek için anket uygulanmıştır. Araştırmanın sonucunda iş yükü ve zaman baskısı açısından nicel taleplerinin bireyin iş-aile çatışması öz-yeterliğini düşürerek tükenmişliği arttırdığı sonucuna ulaşılmıştır.

Anahtar Kelimeler: Nicel İş Talepleri, İş ve Aile Çatışmasını Yönetme Öz-Yeterliği, Tükenmişlik, Termik Santral.

JEL Sınıflandırması: 015, D22, D23.

* Bu çalışma Dokuz Eylül Üniversitesi Sosyal Bilimler Enstitüsü İnsan Kaynakları Yönetimi Programı’nda 15.01.2018 tarihinde kabul edilen "İşin Nicel Talepleri ve Tükenmişlik İlişskisinde İşve Aile Çatışmasını Yönetme Öz-Yeterliğinin Aracllık Etkisi” isimli yüksek lisans tezinden üretilmiştir.

** İzmir Kavram Meslek Yüksek Okulu, Yönetim ve Organizasyon Bölümü, İnsan Kaynakları Yönetimi Programı, E-mail: rahile.guran@kavram.edu.tr, Orcid: https://orcid.org/0000-0002-9130-3482

*** İzmir Katip Çelebi Üniversitesi, Sosyal ve Beşeri Bilimler Fakültesi, Psikoloji Bölümü, E-mail: burcu.guler@ikcu. edu.tr, Orcid: https://orcid.org/0000-0002-6179-7557 


\begin{abstract}
In the increasingly aggravated working conditions, workers/individuals face with excessive amount of work that needs to be done within a limited timeframe. The workload and family demands that must be fulfilled in a short time cause conflict in terms of time in individual's life. The aim of this research is to examine the mediating effect of self-efficacy in managing work and family conflict in the relationship between quantitative demands which workload and time pressure and burnout. . For this purpose, a survey was administered to a total of 409 employees, workin as blue collar employees (worker, master, assistant, master, technician, chief technician) and white collar employees (office staff, engineer, supervisor, expert, manager) to measure the level burnout mediated by self-efficacy on managing family conflict on employees' quantitative demands. As a result of the research, the workload and time pressure as quantitative demands have an impact on burnout with the partial mediation of self-efficacy for managing work-family conflict.
\end{abstract}

Keywords: Quantitative Job Demands, Self-Efficacy for Managing Work-Family Conflict, Burnout, Thermal Power Plant.

JEL Classification: 015, D22, D23.

\title{
I. Giriş
}

Çalışma yaşamı içinde pek çok talep barındırarak, çalışan bireyi stresörler bağlamında kuşatmaktadır. Talep denilen olgu, çevrenin ne kadar uyaran barındırdığı ile ilgili olup mutlaka dikkat edilmesi ve tepki verilmesi gereken bir konudur. Kısaca talep "yapılması gereken şey" olarak ifade edilebilir. Her işin "yapılması gerekenler"i olduğu için her işin de bir iş talebi barındırdığını ifade etmek yanlış olmayacaktır. Daha net bir şekilde ifade etmek gerekirse, iş talepleri işin fiziksel, psikolojik, sosyal ya da örgütsel özellikleri olup, fiziksel ve/veya psikolojik (örneğin bilişsel, duygusal) çaba gerektiren ve bu nedenle belirli fiziksel ve/veya psikolojik maliyetleri barındıran bir olgudur (Schaufeli, 2004: 296). Hemen her işte var olan iş talepleri çalışanların ayak uydurmaları gereken, kendi kaynaklarının mücadele için yeterli olmadığ durumda da stres yaratan koşulları içinde barındırmaktadır. Bir diğer anlatımla, Karasek (1979)'in İş Talepleri ve Kaynakları modeli açısından, iş talepleri çalışanların kaynak olarak ifade edilebilecek karar serbestisi düşük olduğunda ya da birey işi kontrol edemediğinde, baş edilemeyecek duruma gelmekte ve bu durumda birey yüksek düzeyde gerilim ile işe yönelik düşük düzeyde motivasyon ile karşı karşıya kalmaktadır. İş ile ilgili psiko-sosyal riskler içinde önemli bir yeri olan iş yükü; içeriğinde fazla çalışma, makina devir hızları, zaman baskısı ve iş bitim tarihlerinin baskısı konularını barındırmaktadır. Ayrıca yeni ortaya çıkan ve artan psikososyal tehlike olarak uzun çalışma saatleri ve işin yoğunlaşması konularının önemi de giderek artı̧ göstermektedir (Vatansever, 2014: 120).

$\mathrm{Bu}$ çalışmada, iş talepleri olarak belirlenmiş olan iş yükü ve zaman baskısının termik santrallerde çalı̧an bireyler üzerinde, kronik iş stresi olarak da tabir edilebilecek tükenmişlik üzerindeki etkisi incelenmektedir. Çalışmanın alan araştırmasının yapıldığı termik santrallerdeki çalışma koşullarındaki zorluklar genellikle bu alanda çalışmanın psiko-sosyal risk ve tehlike barındırdığına işaret etmektedir (Lerman vd., 1990: 281; Yu vd., 2008: 156). Aslında günümüzde hemen her sektördeki çalışma ortamında yaşanan artan iş yükü, çalışma temposu, uzun çalışma saatleri gibi 
iş talepleri, çalışanların psikolojik ve fiziksel iyilik halini olumsuz yönde etkilemektedir. İş yükü, zaman baskısı, fazla mesaili çalışma, vardiyalı çalışma gibi taleplerle, zorlaşan çalışma hayatı, bireylerin özel yaşamlarında ve aile ile ilgili konularda sıkıntı yaşamalarına da neden olmaktadır. Giderek artan çalışma zamanı nedeniyle, aileye ayrılan zaman ve ilginin eksilmesi, bireyin iş ve aile arasında kalmaktan ötürü zorlanmasına sebep olmaktadır. Buna bağlı olarak, iş ve özel yaşam ya da aile arasında çatışma gündeme gelmektedir. Bir diğer ifadeyle, psiko-sosyal tehlike olarak fazla mesai yapma ve uzun çalışma, psiko-sosyal risk olarak iş ile aile yaşamı arasındaki çatışmaya neden olmakta, bunun sonucunda da stres, tükenmişlik ve depresyon gibi olumsuz duygu durumları baş göstermektedir (Vatansever, 2014: 126). Karasek’in İş Talepleri ve Kaynakları modeli çerçevesinde, iş taleplerinin yoğun olarak yaşanması sonucunda bireyde gözlenebilecek tükenmişlik düzeyinde, iş ve aile çatışmasını yoğun olarak yaşaması bireyin hem iş hayatını hem de aile hayatını olumsuz etkileyebilecektir. Bağlı olduğu işletme ile ailesi arasında sıkışan çalışanın psikolojik iyilik hali olumsuz etkilenebilecektir. Sürekli ve yoğun olarak, iş ve aile arası çatışma kaynaklı strese maruz kalmak çalışanda tükenmişliğe yol açabilmektedir. Tükenmişlik, son yıllarda çalışma yaşamının en fazla incelenen konuları arasına girerek yazında yerini almıştır. İş ve aile arasındaki zamansal açıdan dengenin bozulması iş ve ailevi sorumluluklar açısından çatışma yaşanmasını kaçınılmaz kılmıştır. Tüm bu nedenlerden dolayı tükenmişliğe neden olan iş ve aile talepleri arasındaki uyumsuzluğu yönetmede bireyin sahip olduğu öz-yeterliğin, bireye özgü bir kaynak olarak, tükenmişlik üzerinde nasıl bir etkisinin olduğunun incelenmesi önem arz etmektedir.

\section{Literatür Taraması}

Yukarıda, çalışmanın amacında da belirtildiği gibi, nicel iş talepleri olarak iş yükü ve zaman baskısı hakkında bilgi verildikten sonra, aracı değişken olarak iş ve aile çatışması üzerinde durulacaktır. İş ve aile arasındaki çatışmayı yönetmede bireyin kendine olan inancını ifade eden öz-yeterliğin bir kaynak olarak aracı rolü olabileceği varsayılmaktadır. Son olarak ise, iş talepleri ile baş edilemediğinde ortaya çıkma olasılığı olan tükenmişlik sendromu hakkında açıklama yapilacaktir.

\section{I. Nicel İş Talepleri}

Strese neden olabilecek işyeri faktörleri olan psiko-sosyal tehlikeler, çalışma ortamı ve beşeri faktörler arasındaki etkileşimi vurgulamaktadır. Mesleki koşullar ile beşeri faktörler arasındaki negatif etkileşim, duygusal rahatsızlıklara, davranış problemlerine, biyokimyasal ve nörohormonal değişikliklere, zihinsel ya da fiziksel rahatsızlıklara neden olmaktadır. Çalışma koşulları ve beşeri faktörler dengede olduğunda ise işte ustalık ve kendine güven duygusu oluşmakta ve bu durum bireyin motivasyonunu, çalışma kapasitesini ve memnuniyetini artırıp iyilik haline olumlu katkıda bulunmaktadır (Workplace Stress Report, ILO, 2016: 2). Çalışma yaşamında, 2000'li yıllarla birlikte önemi giderek artan psiko-sosyal riskler ILO tarafından işin örgütlenmesi ve yönetimi, 
çevresel ve örgütsel koşullar ile işçilerin uzmanlığı ve gereksinimleri arasındaki etkileşime bağlı olarak tanımlanarak, iş taleplerinin bireyin kaynakları ile uyumlu bir şekilde sürdürülmesine vurgu yapmaktadır. Bazı kaynaklarda tehlike ile risk ayrımına odaklanılsa da, psiko-sosyal tehlike ile risk arasında ayrım yapmayan Leka ve Cox (2010)'a göre, Avrupa Birliği’nde kavram şu şekilde tanımlanmaktadır: "psikolojik, sosyal ve fiziksel açılardan zarar verme potansiyeli olan, iş tasarımı, işin örgütlenmesi ve yönetimi ile sosyal ve çevresel bağlama ilişkin özellikler" (Cox vd., 2000: 14'den aktaran Leka ve Cox, 2010: 125). Bu bağlamda, iş talepleri de psiko-sosyal risk ya da tehlike olarak değerlendirilmektedir.

İş talepleri, bireylerin fiziksel veya zihinsel çaba sarf ederek cevap vermeleri gereken rol gereksinimleri, beklentileri ve normlarla ilgili yapısal veya psikolojik taleplerdir (Voydanoff, 2005: 823). İş talepleri, sürekli fiziksel ve psikolojik çaba veya beceri gerektiren ve bu nedenle belirli fizyolojik ve psikolojik maliyetlerle ilişkilendirilen, işin fiziksel, sosyal veya örgütsel yönlerini de ifade etmektedir (Schaufeli, 2004: 296; Xanthopoulou vd., 2007: 122). Bu talepler arasında önemli biri olan nicel iş talepleri, bireyin işi ile ilgili yerine getirmesi gereken görevleri gerçekleştirmek için zaman ve iş miktarı açısından karşılaştığı uyumsuzluğu değerlendirmek amacıyla kullanılmaktadır (Şahan, 2016: 26). İşe ilişkin özelliklerden doğan ve kişide stres yaratan iş yükü, zaman baskısı gibi yordayıcılara işin nicel talepleri denmektedir. İşin nicel talepleri, işin gereklerinden doğan iş yükünün fazlalaşmasıyla kişinin özel yaşamında kalan boş zamanını azaltıp işin ev, özel yaşam, aileye etkilerinin artmasına sebep olan yüklerdir.

Bir işi yapmak için belirli bir zaman göz önüne alındığında, yatırım yapılan emek miktarı, tamamlanması gereken işin miktarına ve bu işin gerçekleştirilmesi için çalı̧ma hızına bağlıdır. Hız ve iş miktarının bu iki yönünü belirtmek için iki terim kullanmak yerine sıklıkla iş yükü terimi kullanılmaktadır. Yüksek iş yükü, yüksek iş miktarını ve yüksek hızda yapılan çalışmayı gösterir. Yapılacak işin miktar ve hızını ilgilendiren, fiziksel ve psikolojik çabaları gerektiren çalışma ortamının unsurları ise işin nicel taleplerini oluşturmaktadır (Veldhoven, 2014: 121). Yapılacak iş miktarının iş yükünü arttırması beklenirken, çalışma hızının da zaman baskısını arttırması beklenmektedir. Bu sebeple, işin nicel taleplerinin gözlemlenebilir boyutlarını iş yükü ve zaman baskısı temsil etmektedir.

Karasek (1979)'e göre aşırı iş yükü, iş talepleri bireyin yeteneklerini aştı̆̆ı zaman ortaya çımaktadır. Aşırı iş yükü çevresel bir iş stresi unsurudur ve organizasyonlarda aşırı iş yükünün karşllığında iş stresinin etkilerini hafifleten çevresel bir unsura ya da bireyin sahip olabileceği bir kaynağa ihtiyaç vardır (Karasek, 1979: 287). Bu bağlamda, iş ile aile arasında işin nicel taleplerinden ötürü bir baskılanma yaşayan birey için bu durumu yönetmeye ilişkin, olumsuzluğu hafifletmek adına öz-yeterlik algısı kaynak olarak görülebilir. Aşağıda önce, iş ve aile arasında yaşanan çatışma olgusuna değinilip sonrasında çatışmayı yönetmeye yarayan öz-yeterlik üzerinde durulmaktadır. 


\section{2. İş ve Aile Çatışması}

İş ve aile arasında yaşanan çatışma “Çalışma Yaşamında Güvenlik ve Sağlık Avrupa Ajansı”nın 2007 yılında yayınlamış olduğu uzman görüşlerine dayanan raporunda, iş sağlığg ve güvenliğinde yeni ortaya çıkan psiko-sosyal risklerin beş ana başlı̆̆ından biri olarak, müdahale edilmesi gereken alanlardan biridir (Vatansever, 2014: 120). Bunun önemli bir sebebi, bireyin yaşamında çalışma adına ayrılan zamanda giderek artış yaşanması ve özel yaşama ayrılan zamanın da buna bağlı olarak düşme eğiliminde olmasıdır.

Çalışmanın zaman içinde geçirdiği evrime bakıldığında, zaman konusunun özellikle sanayi ile birlikte insanoğlunun hayatında önemli bir yer kapladığını görmekteyiz. Sanayi öncesindeki üretim, aileler tarafından kendi tüketimlerini sağlamak amacıyla evlerde yapılırken sanayi ile birlikte fabrikaların kurulmasıyla üretim ev ve aileden uzakta gerçekleşmeye başlamıştır. Dolayısıyla sanayi öncesi dönemde üretime bağlı olarak bireylerin iş ve aile alanları arasında keskin sınırlar bulunmuyorken, sanayileşmeyle ev ve işyeri olarak alanlar arasında hem zaman hem de mekânsal ayrım gerçekleşmiştir (Kapız-Özen 2002: 139). Sonrasında, özellikle küreselleşmeyle birlikte artan rekabet sanayinin erkek egemen işgücünün yanına hizmetler sektöründe çalışmaya başlayan kadın işgücünün de ev dışına çıkıp dışarıda istihdam edilmesine yol açmıştır. Kadınların evin sınırları dışında çalışmaları ve iş yaşamının talepleriyle karşılaşmaları nedeniyle, emeğin yeniden üretiminde önemli olan evdeki rol ve sorumluluklarına çalışma yaşamının sorumlulukları da eklenmiştir. Çalışma yaşamında ve özellikle iş ortamında yaşanan zaman ve mekân ayrılığı, erkeğin de ev yaşamının taleplerine cevap vermesini gerektirmiştir. Bu durumla, iş ve aile yaşamı dengesinin kurulmasında kadın ve erkek her iki alandaki taleplerin karşılanması amacıyla ortak bir şekilde hareket etmek durumunda kalmışlardır (Gözükara-Yıldız, 2014: 97).

Ayrıca, kadınların işgücüne katılımının artmasının yanı sıra, aile yapılarındaki değişiklikler, iş dışında farklı yerlerde işe yönelik görevlerin yerine getirilmesini sağlayan teknolojik gelişim ile evden çalışmanın artması (Hill vd., 1998: 667) iş ve ev arasındaki sınırları bulanıklaştırmıştır. Bireyler için, bu durum çalışma zamanı ve çalışma zamanı dışı yaşamların arasında müdahale veya çatışma potansiyeli yaratmıştır (Peeters vd., 2005: 44). Çatışmanın meydana gelebilmesi için, mevcut duruma etki eden bir engel ya da bir müdahalenin olması gerekmektedir. Demerouti ve diğerleri (2004), iş yaşamıyla aile yaşamı arasında, iş yaşamından ya da ev yaşamından kaynaklı bir müdahalenin çatışmayı doğurabileceğini vurgulamışlardır. Bu amaçla yapmış oldukları çalışmada, iş yükü ve zaman baskısı gibi iş taleplerinin işin eve müdahalesini (work - home interference) arttırarak, bireylerde depresifliğe ve psikolojik kökenli bedensel rahatsılıklara neden olduğunu belirtmişlerdir. Bireylerin eve gergin ve yorgun olarak gelmelerinin yeterince dinlenip, iyileşememelerine sebep olduğunu ortaya koymuşlardır. Bu sebeple iş kaynaklı taleplerin evdeki taleplerin yerine getirilmesini engelleyerek iş-aile çatışmasını (work-family conflict) oluşturduğunu ifade etmişlerdir. Leiter ve Durup’ın 1986 yılında yapmış oldukları araştırmada da, işin eve müdahalesinin (work - home interference) duygusal tükenmeyi arttırarak, bireylerin aile yaşamıyla ilgili olan evlilik doyumunu düşürdüğü sonucunu da desteklemişlerdir (Demerouti vd., 2004: 131 - 145). 


\section{3. İ̧ ve Aile Çatışmasını Yönetmede Öz-Yeterlik}

Hennessy ve Lent (2008), sosyal bilişsel kuramın ${ }^{1}$ iş aile çatışmasından kaynaklı çoklu rol katılımının olumlu yönlerini görmek için önemli bir bakış açısı sunduğunu belirtmişlerdir. Sosyal bilişsel kuram, insanların farklı yaşam rolleri arasındaki çatı̧̧mayı nasıl algıladıklarını ve yönettiklerini anlamaya yöneliktir. Bu kuram doğrultusunda, Bandura (1997)'ya göre özyeterlik, kişinin belirli davranışları veya eylem yollarını icra etme kabiliyetlerine ilişkin kişisel inançları ile ilgilidir. Öz-yeterlik inançları bireylerin davranış ve davranış tercihlerini, engellerle, bilişsel stratejilerle ve duygusal durumlarla karşılaştıklarında sebat etme düzeyinin belirlemesine yardımcı olur (Hennessy ve Lent, 2008: 371). Bandura (1977), bireyin algıladığı öz-yeterlik ne kadar güçlü olursa çabanın da o denli aktif olacağını belirtmiştir.

Spychala (2009), 363 asistan üzerinde proaktif çalışma davranışlarını ölçmeye yönelik yapmış olduğu araştırmada, yüksek zaman baskısı olan işlerde çalışanların öz-yeterlik seviyesinin arttığını ve dolayısıyla daha proaktif davranış gösterdiklerini belirtmektedir. Bir olay henüz meydana gelmeden önce sorunları öngörme ve bireyin buna yönelik olumlu adımlar atması bireyin proaktif davranış göstermesidir. Proaktif bir yapıda olan birey, içinde bulunabileceği olumsuz durum için zamanın ötesinde düşünerek istikrarlı bir şekilde sürekli iyileştirmenin nasıl sağlanacağı konusunda farkındalığı yüksek olan ve adımlar atan bireydir. Zamanın baskı olarak ortaya çıkması, çalışanın sorunları öngörmesini ve buna bağlı olarak olumlu adımlar atmasını gerekli kılmaktadır. Bireyler aile ve iş taleplerinden kaynaklı yaşanan aile ve iş arasındaki rol çatı̧̧malarında, öz-yeterlik göstererek proaktif davranışa ulaşılırlar. İşve aile çatışmasında bireyin roller üzerindeki dengeyi kurmaya yönelik, rollerin değişim hızını yakalama ve rol değişimlerine uyum sağlama, harekete geçme, iş ve ilişkiler konusunda azmetme gibi başarılı davranışlar sergilemesi bireyin proaktif davranışla ilgili bireysel bir öncül olan öz-yeterlik göstermesinin sonucu olabilir. Dolayısıyla, iş ile özel yaşam arasındaki çatışmaya yönetebileceğine dair inancın, bireyi güçlü kılarak, nicel iş talepleri ile tükenmişlik arasındaki ilişkide yaşanan stresi baskılayacağı düşünülmektedir.

\subsection{Tükenmişlik}

İş Güvenliği ve Sağlık İdaresi (Occupational Safety and Health Administration-OSHA), potansiyel olarak tehlikeli çalışma ortamları konusundaki farkındalığı arttırmak için araştırmaların gerekli olduğu alanlardan birini işs stresi olarak belirlemiş̦tir. Stres; harici uyaranlar, durumsal taleplerin algılanı̧̧ı, psikolojik durumlar ve fizyolojik reaksiyonlar da dahil olmak üzere birçok konuyu belirtmek için kullanılmıştır (Jackson ve Maslach, 1982: 63). Bireyler tükenmişlik içinde iken düşük bir performans ortaya koymakta, işe odaklılıkta zorlanmakta ve uygun olmayan davranışları sergileyebilmektedirler. Tükenmişlik günümüzde yoğun iş ilişkileri ve stresli iş yaşamının sonucu olarak sıklıkla görülebilecek bir olgudur (Naktiyok ve Kaygın, 2012: 24). Dolayısıyla, iş

1 Bandurảnın (1977) “sosyal bilişsel kuramı” bilgi edinmenin öğrenmenin önemli bir unsuru olması sebebiyle insan davranışlarının modelleme yoluyla oluştuğunu açılar. Bireyler, çevrelerini gözlemleyerek yeni davranış kalıplarına dair bilgi sahibi olur. Edinilen bu bilgiler, eylemi gerçekleștirmek için bir rehber görevi görür. 
taleplerinin bireyin kaldırabileceğinden daha yüksek olmasının tükenmişlik yaratabileceği ve bunun bireyin psikolojik iyilik halini düşürerek çalıştığı işletmeye performans düşüklüğü olarak olumsuz yansıyacağı açıktır.

Freudenberger (1974) tükenmişliği, kişinin kendisinden aşırı enerji talebi göstermesi beklenirken bu durum karşısında öz kaynakları ile talebi karşılayamaması durumunda ortaya çıkan zorlandığını hissetmek, başarısızlık hissi, yıprandığını ve bitkinliğini daha hassas bir şekilde fark etmesi olarak tanımlamaktadır (Freudenberger, 1974: 159). Kristensen vd. (2005) de, tükenmenin sadece yorgunluk ve bitkinlik olmadığını yorgunluğun ve bitkinliğin kişinin yaşamındaki belirli alanlara ve durumlara yansıması olduğunu belirtmişlerdir (Kristensen vd., 2005: 196). Araştırmacılar tükenmişliği, kişisel tükenmişlik, işle ilgili tükenmişlik ve müşteri ile ilgili tükenmişlik olmak üzere üç boyutta tanımlamışlardır. Kişisel tükenmişlik, bireyin mesleki durumundan bağımsız olarak yaşam deneyimlerinden kaynaklanan fiziksel ve psikolojik bitkinlik derecesi olarak tanımlanmıştır. İşle ilgili tükenmişlik, birey tarafından işi ile ilgili olarak algıladığı fiziksel ve psikolojik bitkinlik derecesi olarak, müşteri ile ilgili tükenmişlik ise bireyin işle ilgili müşterilerden kaynaklanan psikolojik ve fiziksel bitkinlik derecesi olarak tanımlanmaktadırlar (Kristensen vd., 2005: 197).

\section{Yöntem}

\section{I. Amaç}

$\mathrm{Bu}$ araştırmanın amacı, işin nicel talepleri olan iş yükü ve zaman baskısının tükenmişlikle ilişkisinde iş ve aile çatışmasını yönetme öz-yeterliğinin aracılık etkisini incelemektir. İş sağlı̆̆ psikolojisi açısından önemli olan psiko-sosyal tehlike ve riskler yazını doğrultusunda özellikle nicel iş taleplerine odaklanmaktadır. İş Talepleri ve Kaynakları (JDR) yazınından yararlanılarak, işyerindeki nicel taleplerin tükenmişlik üzerindeki etkisi çalışmanın ana konusunu oluşturmaktadır. Bu doğrultuda, bireyin iş-özel yaşam dengesini sağlamaya dair öz-yeterliğin bu ilişkideki rolü üzerinde de durulmaktadır. Çalışma, fazla mesai, vardiyalı çalışma, kısa mola süreleri gibi zorlu çalışma koşullarında çalışan büyük çoğunluğu mavi yakalı olan termik santral çalışanlarının çalışma koşullarına dikkat çekmektedir. Ülkemizde termik santral çalışanlarının daha önce çalışma koşullarının psikolojik açıdan incelenmesine yönelik olması konunun özgün tarafını oluşturmaktadır.

Özetle, bu çalışmayla birlikte, işin nicel taleplerinin iş ve aile çatışması öz-yeterliği aracılığıyla tükenmişliğe olan etkisi anlaşılmaya çalışılacaktır. Bir diğer ifadeyle, iş yükü ile zaman baskısı nicel talepleri ile tükenme arasındaki ilişkide iş ve aile çatışması öz-yeterliğinin aracılık etkisi incelenecektir.

\section{2. Örneklem}

Çalışmanın örneklemini yaşları 20 ile 67 arasında değișen, \% 5,9 u kadın (24), \% 94,1 i erkek (385), toplamda 409 termik santral çalışanı (\%83,1 mavi yaka, \%16,9 beyaz yaka) oluşturmaktadır. 
Çalışanların eğitim durumları sırasıyla; ilkokul (\%10,3), ortaokul (\%12,7), lise (\% 57,7), ön lisans (\% 10), lisans $(\% 7,6)$, yüksek lisans ve üstü $(\% 1,7)$ şeklindedir. Örneklemin genel olarak demografik yapısı, "Demografik ve Tanımlayıcı İstatistikler" başlıklı Tablo 2'de özetlenmiş, bulgular kısmında tanımlayıcı istatistikler aracılığıyla da detaylı bir şekilde açıklanmıştır.

\subsection{Kullanılan Ölçekler}

Çalışanlar üzerinde yapılan bu uygulama için, aşağıda ölçek bilgileri verilmiş olan ölçeklerin kullanıldığı anket formu geliştirilmiştir. Anketler, termik santralde idarenin yetkilendirdiği bir görevliyle birlikte, yazar tarafından çalışanlara dağıtılmıştır. Katılımcılardan elde edilen cevaplar, IBM SPSS Statistics Version 20.0’a aktarılarak analiz edilmiştir. Belirtilen tüm bu ölçeklere ilişkin detaylı bilgilere Tablo l'de yer verilmektedir.

\subsection{Kopenhag Psiko-Sosyal Risk Ölçeği (COPSOQ)}

COPSOQ Ölçeği’nin gelişimi, ilk olarak 1995 yllında Kristensen ve Vilhem Borg tarafından Danimarka'da Ulusal Mesleki Sağlık Enstitüsünde psiko-sosyal araştırma grubunun kurulmasıyla başlamıştır. Önceleri enstitü, işyerinde fiziksel, kimyasal ve ergonomik faktörlere öncelik vermişti. Daha sonra, iş yerinde psiko-sosyal faktörlerin değerlendirilmesi ile ilgili ciddi sorunlar yaşayan çeşitli çalışma grupları tarafından yüksek standartlı bir ölçüme ihtiyaç duyulmuştur. Karasek (1979) Talep Kontrol Modeli’nden üç boyut ve Siegrist'in (1996) Çaba Ödül Dengesi Modelinden iki boyut alınarak COPSOQ oluşturulmuştur (Kristensen, 2010: 150).

Çalışma ortamındaki işin özelliklerinden doğan iş yükü ve zaman baskısını içeren nicel talepler, COPSOQ Ölçeğinde 4 madde ile ölçülmüştür. Ölçekte yer alan nicel talep sorularından iş yükünü ölçmeye yönelik sorular: "Çok hızlı çalışmak zorunda kalır mısınız?" ve "İş yükünüz eşit dağılmadığı için birikir mi?” şeklindedir. Zaman baskısını ölçmeye yönelik sorular ise: “Tüm görevlerinizi tamamlamak için zamanınızın yetmediği olur mu?” ve "Fazla mesai yapmak zorunda kalır mısınız?" şeklindedir. Nicel talepler ölçeğine ilişkin cevap seçenekleri "1 - Asla/ Neredeyse Hiç" dan "5-Her zaman” seçeneğine kadar değişen 5'li Likert Ölçeği kullanılarak oluşturulmuştur. Ölçeğin her iki boyutunun güvenilirlik düzeylerine ilişkin Cronbach alpha değerleri şu şekildedir: İş yükü= 0,78 , Zaman baskısı= 0,75 . İş yükü ve zaman baskısı birlikte incelendiğinde nicel taleplerin Cronbach alpha değeri 0,86 olarak bulunmuştur.

\subsection{2. İş ve Aile Çatışması Yönetme Öz-yeterliği Ölçeği}

Ölçeğin orijinal formu İbranice'dir. İki alt boyuttan oluşmaktadır. Ölçeğin alt boyutları "İşAile Çatışmasını Yönetme Öz-Yeterliği" ve "Aile-İş Çatışmasını Yönetme Öz-Yeterliği" olarak belirlenmiştir. Ölçekteki alt boyutlardan "İş-Aile Çatışmasını Yönetme Öz-Yeterliğì" iş kaynaklı 
güçlüklerin aile yaşamını zora soktuğu durumlarda yaşanan çatışmaları yönetme öz-yeterliğine; "Aile-İş Çatışmasını Yönetme Öz-Yeterliği” ise aileden kaynaklı zorlukların işe yansıması sonucu ortaya çıkan çatışmayı yönetme öz-yeterliğine dair puanlar vermektedir. Ölçeğin İngilizce’ye uyarlaması ise Hennessy (2005) tarafından yapılmıştır. Yapılan çalışmada ölçeğin İbranice olan 10 maddelik formundaki iki maddenin ilgili faktörlere yük vermediği görülmüş ve 8 maddenin ise orijinalindeki şekliyle çalıştığı görülmüştür (Amanvermez ve Denizli, 2016: 6). Cronbach Alpha katsayıları, ölçeğin toplam puanı için 0,85; İAÇY öz-yeterliği boyutu için 0,92; AİÇY özyeterliği alt boyutu için 0,83 olarak hesaplanmıştır.

\subsubsection{Kopenhag Tükenmişlik Envanteri Ölçeği}

Çalışmamızda ülkemizde sıklıkla kullanılan Maslach Tükenmişlik Envanteri’nden farklı olarak, COPSOQ (Kopenhag Psiko-sosyal Anketi)'da yer alan Copenhagen Tükenmişlik Envanteri tercih edilmiştir. Kristensen vd. (2005), tükenmişlik değerlendirmesi için yeni bir araç olan Kopenhag Tükenmişlik Envanterini geliştirirken yapmış oldukları yazın incelemesinde, mevcut yazında tükenmişlikle ilgili tanımların birbirine benzediğini, tükenmenin sadece yorgunluk ve bitkinlik olmadığını, yorgunluğun ve bitkinliğin kişinin yaşamındaki belirli alanlara ve durumlara yansıması olduğunu belirtmişlerdir (Kristensen vd., 2005: 196). Tükenmişliği, kişisel tükenmişlik, işle ilgili tükenmişlik ve müşteri ile ilgili tükenmişlik olmak üzere üç boyutta tanımlamışlardır. Kişisel tükenmişlik, bireyin mesleki durumundan bağımsız olarak yaşam deneyimlerinden kaynaklanan fiziksel ve psikolojik bitkinlik derecesi olarak tanımlanırken, işle ilgili tükenmişliği, bireyi tarafından işi ile ilgili olarak algıladığı fiziksel ve psikolojik bitkinlik derecesi olarak, müşteri ile ilgili tükenmişliği ise bireyin işle ilgili müşterilerden kaynaklanan psikolojik ve fiziksel bitkinlik derecesi olarak tanımlamaktadırlar (Kristensen vd., 2005: 197). Wan-Yu vd. (2007) Kopenhag Tükenmişlik Envanteri analizinden sonra, tükenme durumunun daha açık bir şekilde ölçüldüğünü belirtmektedir (Kula, 2011: 38). Bu nedenle, bu çalışmada Kopenhag Tükenmişlik Envanteri (CBI) işle ilgili tükenmişlik alt ölçeği kullanılmıştır. Ölçeğin güvenilirlik düzeyine ilişkin Cronbach alpha değeri ise 0,93 şeklindedir. Ölçeklerle ilgili özet bilgilere Tablo 1'de yer verilmiştir.

Tablo I: Ölçeklerle İlgili Özet Bilgi

\begin{tabular}{|c|c|c|c|c|}
\hline Değişken adı & $\begin{array}{c}\text { Ölçekteki ifade } \\
\text { sayısı }\end{array}$ & Boyutları & $\begin{array}{l}\text { Güvenilirlik düzeyi } \\
\text { (Cronbach alpha) }\end{array}$ & $\begin{array}{c}\text { Referans } \\
\text { bilgileri }\end{array}$ \\
\hline İşin Nicel Talepleri & 4 & $\begin{array}{c}\text { İş Yükü (2 ifade) } \\
\text { Zaman Baskısı (2 ifade) }\end{array}$ & $\begin{array}{l}0,78 \\
0,75\end{array}$ & Şahan (2016) \\
\hline $\begin{array}{l}\text { İş ve Aile Çatışmasını } \\
\text { Yönetme Öz-yeterliği }\end{array}$ & 8 & $\begin{array}{l}\text { İAÇYÖ (5 ifade) } \\
\text { ȦÇYÖ (3 ifade) }\end{array}$ & $\begin{array}{l}0,92 \\
0,83\end{array}$ & $\begin{array}{l}\text { Amanvermez ve } \\
\text { Denizli (2016) }\end{array}$ \\
\hline Tükenmişlik & 7 & Tek boyut ( 7 ifade) & 0,93 & Kula (2011) \\
\hline
\end{tabular}




\section{Bulgular}

\section{I. Tanımlayıcı İstatistikler}

Bu bölümde, araştırmaya katılanlarla ilgili bazı demografik bilgilere Tablo 2'de yer verilmiştir. Bu tabloda görüldügü gibi araştırmaya 409 kişi katılmış olup, kadınların oranı \%5,9 ve erkeklerin oranı \%94,1'dir. Araştırmaya konu olan çalışanın yaş durumuna bakıldığında minimum 20, maksimum 67 olmak üzere yaş ortalaması 37'dir. Medeni durum açısından değerlendirildiğinde bekarların oranı \%20,3, evlilerin oranı \%75,3, dul ve boşanmışların oranı ise \%4,4'dir. Eşi çalışmayan oranı \%61,9'dur. Çalışanın eğitim durumuna bakıldığında, lise mezunları en büyük paya sahiptir ve oranları \%57,7'dir. Lise mezunlarını, ortaokul mezunları \%12,7 ile ilkokul mezunları \%10,3, ön lisans \%10, lisans mezunları \%7,6, yüksek lisans ve üstü \%1,7 ile takip etmektedir. Çocuk sayısı demografik değişkenine deneklerin \%28,6'sı cevap vermemiştir. Çocuğu olan çalışan oranı \%71,4'tür. 1 çocuklu çalışanların oranı \%27,4, 2 çocuklu çalışan oranı \%57,5, 3 çocuklu çalışan oranı \%11,3, 4 çocuklu çalışan oranı \%2,1, 5 çocuklu çalışan oranı \%1,7'dir. Deneklerin \%21,8’i eşi ve çocuğu dışında, ailede bakmakla yükümlü oldukları bireylerin olduğunu belirtmişlerdir. Bakmakla yükümlü olunan birey sayısına \%12,4’ü 1 kişi, \%6,4’ü 2 kişi, \%2'si 3 kişi, \%1’i de 4 kişi yanıtını vermişlerdir. Ortalama aylık ücret durumu değerlendirildiğinde, çalışanların \%52,6'sı 2000 TL ve altı, \%28,5’i 2000 TL-3000 TL arasında, \% 18,9’u 3000 TL ve üzerinde kazandıklarını beyan etmiştir. "Ailenizin ekonomik durumu için geliriniz ne kadar önemli?” sorusuna \% 51,6’sı gelirinin çok önemli olduğunu, \% 32,1'i önemli olduğunu, \% 6,9'i kısmen önemli olduğunu, \% 3,5’i önemli olmadığını, \% 5,9’u ise hiç önemli olmadığı yanıtını vermişlerdir.

İşteki pozisyon açısından, çalışanların \%34'ü işçi, \%22'si usta yardımcısı, \%14,2'si usta, \%4,6'sı ustabaşı, \%5,6'sı teknisyen, \%2,6'sı başteknisyen, \%1'i üretimde yönetici, \%4,2'si mühendis, \%9'u büro elemanı, \%1,2'si şef, \%0,5'i uzman, \%1'i büroda yönetici olarak çalışmakta olduklarını ifade etmiştir. Unvanlar değerlendirildiğinde mavi yakalı çalışan (işçi, usta yardımcısı, usta, ustabaşı, teknisyen, başteknisyen) oranı \%83,1'dir. Çalışanların kıdem yılı karşılaştırıldığında, toplam kıdem yılı ortalamasının 10 yıl olduğu görülmüştür. "Vardiyalı çalışıyor musunuz?" sorusuna çalışanların \%57,7'si evet, \%42,3’ü hayır cevabını vermiştir. Çalışma şekillerine bakıldığında \%97,5’i tam zamanlı, \%2'si yarı zamanlı, \%0,5’i çağrı üzerine çalışmaktadır. Çalışma şekli tercihinde ise \%87,4 tam zamanlı çalışmak isterken, \%3,7’i çağrı üzerine çalışmak istediklerini belirtmiştir.

Çalışanların \%70,8’i belirsiz süreli sözleşme ile çalışırken, \%29,4’ü belirli süreli çalıştıklarını belirtmişlerdir. Çalışanların \%92,3’ ü asıl işverene bağlı, \%7,8’i alt işverene bağlıdır. Günlük çalışma saatlerinde 8 saat çalışan \%45,5'dir, 10 saat çalışan \%46,9'dir, 10 saat üzeri çalışan \%0,2'dir. Çalışanların \%58,1'i haftada 6 gün, \%41,7’si 5 gün çalışmaktadır. Çalışanların \%57,7'si vardiyalı çalışmaktadır. Vardiyalı çalışmaktan \%32,1'i memnun değildir, \%19,3'ü de kararsız olduğunu belirtmiştir. Çalışanın iş memnuniyeti sorusuna \%19,2'si çok memnun, \%43,7'si memnun, \%18,9'u kararsız, \%10,2'si memnun değil, \%7,9’u hiç memnun değildir. Çalışanların \%66,8'i sendikalıdır, \%33,5'i sendikadan çok memnun, \%35,6'sı memnun, \%17,1'i sendikadan 
memnuniyetsiz, \%13,8'i sendika memnuniyet durumuyla ilgili kararsızdır. \%32,8’i ise bu soruya cevap vermemiştir. \%86,8’i sendikalı olmayı isterken, \%18,6’sı bu soruya cevap vermemiştir.

Çalışanların \%93,1'lik kısmı fazla mesai yaptıklarını, \%6,9'u fazla mesai yapmadıklarını belirtmiştir. Yapılan bağımsız örneklem t testine göre, birlikte yaşayanların haftalık çalışma saati $(\overline{\mathrm{X}}=49,61, \mathrm{SS}=4,07)$ yalnız yaşayanların haftalık çalışma saatinden $(\overline{\mathrm{X}}=50,91$, ss $=5,15)$ daha düşük gözlemlenmiştir ( $\mathrm{t}(401)=2,58, \mathrm{p}=0,001)$.

Son 1 yılda raporlu olunan gün sayıs1, minimum 1 gün, maksimum 40 gündür. Raporlu olunan gün sayısı ortalaması 4 gün, mazeretsiz devamsızlık gün ortalaması 2,5 gündür.

Tablo 2: Demografik Bilgiler ve Tanımlayıcı İstatistikler

\begin{tabular}{|c|c|c|c|c|c|c|c|}
\hline Değişkenler & Kategori & Sayı & Min. & Maks. & $\overline{\mathrm{x}} /$ Oran (\%) & $\begin{array}{l}\text { Geçerli } \\
\bar{x} / \text { Oran (\%) }\end{array}$ & SS \\
\hline \multirow{2}{*}{ Cinsiyet } & Kadın & 24 & & & 5,9 & 5,9 & \multirow{2}{*}{0,23} \\
\hline & Erkek & 385 & & & 94,1 & 94,1 & \\
\hline Yaş & Diğer & 409 & 20 & 67 & 38,76 & - & 9,71 \\
\hline \multirow{3}{*}{ Medeni Durum } & Bekar & 83 & & & 20,3 & 20,3 & \multirow[t]{3}{*}{0,47} \\
\hline & Evli & 308 & & & 75,3 & 75,3 & \\
\hline & Dul & 18 & & & 4,4 & 4,4 & \\
\hline \multirow{6}{*}{ Eğitim } & İlkokul & 42 & & & 10,3 & 10,3 & \multirow[t]{6}{*}{1,0} \\
\hline & Ortaokul & 52 & & & 12,7 & 12,7 & \\
\hline & Lise & 236 & & & 57,7 & 57,7 & \\
\hline & Ön Lisans & 41 & & & 10 & 10 & \\
\hline & Lisans & 31 & & & 7,6 & 7,6 & \\
\hline & Y. lisans ve üstü & 7 & & & 1,7 & 1,7 & \\
\hline \multirow{3}{*}{$\begin{array}{l}\text { Eşin Çalışma } \\
\text { Durumu }\end{array}$} & Çalışıyor & 66 & & & 16,1 & 19,6 & \multirow[t]{3}{*}{0,48} \\
\hline & Çalışmıyor & 253 & & & 61,9 & 75,3 & \\
\hline & Kısmi Süreli Çalışıyor & 17 & & & 4,2 & 5,1 & \\
\hline \multirow{7}{*}{$\begin{array}{l}\text { Ortalama } \\
\text { Aylık } \\
\text { Ücret }\end{array}$} & 1404 TL ve altı & 32 & & & 7,8 & 7,9 & \multirow[t]{7}{*}{0,78} \\
\hline & $1404 \mathrm{TL}-2000 \mathrm{TL}$ & 182 & & & 44,5 & 44,7 & \\
\hline & $2001 \mathrm{TL}-3000 \mathrm{TL}$ & 116 & & & 28,4 & 28,5 & \\
\hline & $3001 \mathrm{TL}-4000 \mathrm{TL}$ & 42 & & & 10,3 & 10,3 & \\
\hline & $4001 \mathrm{TL}-5000 \mathrm{TL}$ & 20 & & & 4,9 & 4,9 & \\
\hline & $5001 \mathrm{TL}-6000 \mathrm{TL}$ & 8 & & & 2 & 2 & \\
\hline & $6001 \mathrm{TL}-7000 \mathrm{TL}$ & 4 & & & 1 & 1 & \\
\hline \multirow{5}{*}{$\begin{array}{l}\text { Gelirin } \\
\text { Önemi }\end{array}$} & Çok önemli & & & & 51,6 & 51,1 & \multirow[t]{5}{*}{1,10} \\
\hline & Önemli & & & & 32,1 & 31,8 & \\
\hline & Kismen önemli & & & & 6,9 & 6,8 & \\
\hline & Önemli değil & & & & 3,5 & 3,4 & \\
\hline & Hiç önemli değil & & & & 5,9 & 5,9 & \\
\hline
\end{tabular}




\begin{tabular}{|c|c|c|c|c|c|c|}
\hline \multirow{12}{*}{$\begin{array}{l}\text { Mesleki } \\
\text { Pozisyon }\end{array}$} & İşçi & 139 & & 34 & 34 & \multirow[t]{12}{*}{2,86} \\
\hline & Usta yardımcisı & 90 & & 22 & 22 & \\
\hline & Usta & 58 & & 14,2 & 14,2 & \\
\hline & Ustabaşı & 19 & & 4,6 & 4,6 & \\
\hline & Teknisyen & 23 & & 5,6 & 5,6 & \\
\hline & $\begin{array}{l}\text { Baş } \\
\text { teknisyen }\end{array}$ & 11 & & 2,7 & 2,7 & \\
\hline & Üretimde yönetici & 4 & & 1 & 1 & \\
\hline & Mühendis & 17 & & 4,2 & 4,2 & \\
\hline & Büro elemanı & 37 & & 9 & 9 & \\
\hline & Şef & 5 & & 1,2 & 1,2 & \\
\hline & Uzman & 2 & & 0,5 & 0,5 & \\
\hline & Büroda yönetici & 4 & & 1 & 1 & \\
\hline $\begin{array}{l}\text { Toplam Çalışma } \\
\text { Yılı }\end{array}$ & Diğer & 403 & 40 & 10 & & 8,85 \\
\hline \multirow[t]{2}{*}{ Fazla Mesai } & Yapmayan & 28 & & 6,8 & 6,9 & \multirow[t]{2}{*}{0,25} \\
\hline & Yapan & 375 & & 91,7 & 93,1 & \\
\hline \multirow{5}{*}{$\begin{array}{l}\text { İşten } \\
\text { Memnuniyet } \\
\text { Durumu }\end{array}$} & Hiç Memnun Değilim & 31 & & 7,6 & 7,9 & \multirow[t]{5}{*}{1,15} \\
\hline & Memnun Değilim & 40 & & 9,8 & 10,2 & \\
\hline & $\begin{array}{l}\text { Ne Memnunum Ne Memnun } \\
\text { Değilim }\end{array}$ & 74 & & 18,1 & 18,9 & \\
\hline & Memnunum & 171 & & 41,8 & 43,7 & \\
\hline & Çok Memnunum & 75 & & 18,3 & 19,2 & \\
\hline Sendika & Üye & 243 & & 59,4 & 66,6 & 0,47 \\
\hline Durumu & Üye Değil & 121 & & 29,6 & 33,2 & \\
\hline \multirow[t]{2}{*}{$\begin{array}{l}\text { Sendikalı Olma } \\
\text { İsteği }\end{array}$} & İsterdim & 288 & & 70,4 & 86,5 & \multirow[t]{2}{*}{0,33} \\
\hline & İstemezdim & 44 & & 10,8 & 13,2 & \\
\hline
\end{tabular}

\section{2. İlişkiye Yönelik Analizler}

Aşağıdaki korelasyon tablosunda, ankette kullanılan ölçeklere ait değişkenler arasındaki ilişkiyi görmek mümkündür (Tablo 3). Tabloyu özetlemek gerekirse, işin nicel taleplerinin iş yükü ve zaman baskısı boyutlarının birbiri ile anlamlı düzeyde pozitif yönde ilişkili olduğu anlaşılmaktadır. İş ve aile çatışmasını yönetme öz-yeterliği boyutları İAÇY öz-yeterliği ile AİÇY 
öz-yeterliği arasında da pozitif yönde anlamlı bir ilişki söz konusudur ( $r=0,529, p<0,01)$. İş ve aile çatışmasını yönetme öz-yeterliği boyutlarından İAÇY öz-yeterliği ile nicel iş taleplerinin tüm boyutları arasında negatif yönde ve anlamlı ilişki bulunmaktadır. Açıklamak gerekirse, işin nicel talepleri olan iş yükü ve zaman baskısının artış göstermesi ile birlikte İAÇY öz-yeterliği düşüş göstermektedir. İşin nicel talepleri boyutları ile tükenmişlik arasındaki ilişkiye baktığımızda ise işin nicel talepleri boyutlarından iş yükü $(r=0,433, p<0,01)$ ve zaman baskısı $(r=0,446, p<0,01)$ ile anlamlı ve pozitif yönde ilişki göstermektedir. İş yükü ve zaman baskısı arttıkça bireyde tükenmişlik artmaktadır. İş ve aile çatışmasını yönetme öz-yeterliği ve tükenmişlik arasındaki ilişki açısından ise İAÇY öz-yeterliği ile negatif yönde ve anlamlı düzeyde ilişki bulunmuştur (r=0,255, p<0,01). İAÇY öz-yeterliği arttıkça bireylerin tükenmişliği düşmektedir.

Tablo 3: Değişkenler Arası Korelasyon Analizi

\begin{tabular}{|l|l|l|l|l|l|l|l|}
\hline & $\overline{\mathbf{x}}$ & SS & $\mathbf{1}$ & $\mathbf{2}$ & $\mathbf{3}$ & $\mathbf{4}$ & $\mathbf{5}$ \\
\hline İş yükü (1) & 3,55 & 1,09 & 1 & & & & \\
\hline Zaman baskısı (2) & 3,22 & 1,14 & $0,744^{* *}$ & 1 & & & \\
\hline İAÇY öz-yeterliği (3) & 7,14 & 2,21 & $-0,183^{* *}$ & $-0,151^{* *}$ & 1 & & \\
\hline AíÇY öz-yeterliği (4) & 7,74 & 1,96 & $-0,022$ & $-0,028$ & $0,529^{* *}$ & 1 & \\
\hline Tükenmişlik (5) & 3,42 & 1,23 & $0,433^{* *}$ & $0,446^{* *}$ & $-0,255^{* *}$ & $-0,057$ & 1 \\
\hline
\end{tabular}

Not: $\left({ }^{*}\right) p<0,05,\left({ }^{* *}\right) p<0,01$

\subsection{Farklılık Analizleri}

\subsection{Nicel İş Talepleriyle İlgili Farklılık Analizleri}

Cinsiyete göre nicel iş talepleri ilişkisinde herhangi bir farklılık olup olmadığı Bağımsız Örneklem t-testi ile analiz edilmiştir. Nicel taleplerden iş yükünü incelediğimizde, analiz sonuçlarında bağımsız örneklem t-testine göre, iki grup arasında anlamlı bir farklılık görülmüştür $(\mathrm{p}<0,05)$. Analiz sonuçlarına göre, kadın ve erkek çalışanlar, çalışma yaşamındaki iş yükü talebi açısından birbirlerinden farklı tutum sergilemektedir. Kadınların iş yükü algı düzeyleri $(\overline{\mathrm{x}}=4,04, \mathrm{SS}=0,95)$ erkeklere göre $(\overline{\mathrm{x}}=3,52, \mathrm{SS}=1,09)$ daha yüksek gerçekleşmiştir $(\mathrm{t}(407)=2,25, \mathrm{p}=0,025)$.

Haftalık çalışma süresiyle eğitim durumu arasındaki ilişkiye Tek Yönlü Varyans Analizi ile bakıldığında olumlu yönde ve anlamlı bir ilişki olduğu sonucuna ulaşılmıştır $(\mathrm{p}<0,05)$. Yükseköğrenim mezunlarının haftalık çalışma saati $(\overline{\mathrm{x}}=51,62)$, ilköğretim mezunları $\overline{\mathrm{x}}=50,55)$ ve lise mezunlarının $(\overline{\mathrm{x}}=49,11)$ haftalık çalışma saatinden daha yüksek gözlemlenmiştir.

Mesleki pozisyona göre nicel talepler iş yükü ve zaman baskısı boyutları ayrı ayrı olarak Tek Yönlü Varyans Analizi testi ile ölçülmüştür. İş yükünün mesleki pozisyona göre farklılık gösterdiği görülmüştür $(\mathrm{p}<0.05)$.

Günlük çalışma süresi ile işin nicel taleplerinin her iki boyutu arasında korelasyon analizi yapıldığında pozitif yönlü ve anlamlı bir ilişki ölçülmüştür Günlük çalışma süresi arttıkça iş yükü 
ve zaman baskısı artmaktadır (sırasıyla $\mathrm{r}=0,160, \mathrm{p}<0,01 ; \mathrm{r}=0,194, \mathrm{p}>0,01$ ). Haftalık çalışma süresi ile (günlük çalışma saati*çalışma günü sayısı olarak hesaplanmıştır), iş yükü ve zaman baskısı boyutları ilişkine korelasyon analizi ile bakıldığında pozitif yönlü anlamlı bir ilişki ölçülmüştür $(\mathrm{r}=0,101, \mathrm{p}<0,05 ; \mathrm{r}=0,155, \mathrm{p}<0,01)$. Özetle, genel olarak, çalışılan süre ile işin nicel talepleri arasında pozitif ilişki bulunmaktadır.

\subsection{2. İş ve Aile Çatışmasını Yönetme Öz-yeterliği Farkıılık Analizleri}

Analiz sonuçlarına göre, işten eve çatışmayla ilgili olan İAÇY öz-yeterliği açısından erkekler ve kadınlar birbirinden farklı bir tutum izlemektedirler. Cinsiyet ile iş ve aile çatışmasını yönetme öz-yeterliği ilişkisine Bağımsız Örneklem $t$ testi ile bakılmıştır. Erkeklerin $(\bar{x}=7,22, S S=2,18)$, İAÇY öz-yeterliği kadınlardan ( $\mathrm{x}=5,99, \mathrm{SS}=2,35)$ daha yüksek olduğu görülmüştür $(\mathrm{p}=0,008)$. Örneklemimizdeki kadın sayısı ( $\mathrm{n}=24)$, erkek sayısının $(\mathrm{n}=385)$ çok altında olduğu için, sonuçlar hakkında yorumda bulunmak güçtür.

İAÇY öz-yeterliği ile eğitim düzeyi arasındaki ilişkiye Tek Yönlü Varyans Analizi ile bakıldığında, yüksek lisans ve üstü $(\overline{\mathrm{x}}=8,00)$, lise $(\overline{\mathrm{x}}=7,44)$ ve lisans mezunlarının $(\overline{\mathrm{x}}=7,12)$ İAÇY öz-yeterliği, ilkokul mezunlarının $(\overline{\mathrm{x}}=6,42)$ İAÇY öz-yeterliğinden daha yüksektir $(\mathrm{p}<0,05)$. AİÇY öz-yeterliği ile eğitim durumu arasında anlamlı bir ilişki görülmemiştir.

Sözleşme şekli ile iş ve aile çatışmasını yönetme öz-yeterliği ilişkisine Bağımsız Örneklem t-testi ile bakılmıştır. Sözleşme şekline göre, İAÇY öz-yeterliğinin belirli süreli sözleşmeli çalışanlarda $(\overline{\mathrm{X}}=7,5, \mathrm{SS}=2,30)$, belirsiz süreli sözleşmeli çalışanlardan $(\overline{\mathrm{X}}=6,9, \mathrm{SS}=2,01)$ daha yüksek olduğu görülmüştür $(\mathrm{t}(388)=-2,33, \mathrm{p}=0,020)$. AİÇY öz-yeterliği açısından ise sözleşme şekli ilişkisine rastlanılmamıştır.

İşten memnuniyet ile İş ve Aile Çatışması Yönetme Öz-yeterliği arasında korelasyona bakıldığında hem İAÇY öz-yeterliği ile hem de AİÇY öz-yeterliği boyutu ile pozitif yönlü ve anlamlı bir ilişki vardır (sırasiyla $r=0,225, \mathrm{p}<0,01 ; \mathrm{r}=0,164, \mathrm{p}<0,01$ ).

\subsubsection{Tükenmişlik ile Iilgili Farklılık Analizleri}

Toplam çalışma yılı ile tükenmişlik arasındaki ilişkiye korelasyon analizi ile bakılmıştır. İki değişken arasında anlamlı ve negatif yönlü bir ilişsi vardır $(r=-0,200, p<0,01)$. Çalışma süresi arttıkça, kişilerin tükenmişlik düzeylerinin düştüğü görülmektedir. Medeni durum ve tükenmişlik arasında yapılan Bağımsız Örneklem $t$ testine göre, birlikte yaşayanların $(\overline{\mathrm{X}}=3,34, \mathrm{SS}=1,26)$, yalnız yaşayanlara $(\overline{\mathrm{X}}=3,66, \mathrm{SS}=1,09)$ göre tükenmişliklerinin daha az olduğu gözlemlenmiştir $(\mathrm{t}(407)=2,27, \mathrm{p}=0,031)$.

Vardiyalı çalışmaktan memnuniyet ile tükenmişlik arasında yapılan Tek Yönlü Varyans Analizi ile ölçüldüğünde anlamlı ve pozitif yönde bir ilişki ölçülmüştür $(\mathrm{p}<0,05)$. "Vardiyalı çalışmaktan ne kadar memnunsunuz?" sorusuna "hiç memnun değilim” şeklinde cevap verenlerin tükenmişliği 
$(\overline{\mathrm{X}}=4,04)$, vardiyalı çalışmaktan "memnunum” şeklinde cevap bildirenlerin tükenmişliğinden $(\overline{\mathrm{X}}=3,24)$ yüksektir.

İşten memnuniyet ile tükenmişlik ilişkisine korelasyon analiziyle bakıldığında, anlamlı ve negatif yönde bir ilişki ölçülmüştür ( $\mathrm{r}=-0,228, \mathrm{p}<0,01)$. Haftalık çalışma süresi ile tükenmişlik arasında yapılan korelasyon analizinde pozitif yönlü ve anlamlı bir ilişki olduğu görülmüştür $(r=0,147, p<0,01)$

\subsection{Regresyon Analizi ile Tükenmişliği Açıklayan Faktörler}

Araştırmanın genel amacı çalışanların tükenmişlik yaşamalarına neden olabilecek işin nicel talepleri olan iş yükü ve zaman baskısının, iş-aile çatışmasını yönetmede öz-yeterliğin etkisini incelemektir. Bunun için, iş yükü ve zaman baskısı, iş kaynaklı tükenmişlik boyutları ile İAÇY öz-yeterliği ve AİÇY öz-yeterliği arasındaki ilişki incelenmiştir. Araştırmanın hipotezleri şu şekildedir:

H1: İş yükü tükenmişliği olumlu yönde etkilemektedir.

H2: Zaman baskısı tükenmişliği olumlu yönde etkilemektedir.

H3: İAÇY Öz-yeterliği tükenmişliği olumsuz yönde etkilemektedir.

H4: AİÇY Öz-yeterliği tükenmişliği olumsuz yönde etkilemektedir.

Belirlenen bu hipotezleri test etmek amacıyla, çoklu doğrusal regresyon analizi uygulanmıştır. Regresyon analizinde, ilk aşamada demografik değişkenlerin (yaş, çocuk sayısı, mesleki pozisyon, gelirin önemi) etkisi kontrol edilerek, ikinci aşamada belirlenmiş olan bağımsız değişkenlerin etkisine bakılmıştır. Analize ilişkin değerler Tablo 4’te verilmiştir.

Tablo 4: Tükenmişlik İçin Regresyon Analizi

\begin{tabular}{lll}
\hline & $\mathbf{1 .}$ Aşama & $\mathbf{2 . \text { Așama }}$ \\
Cinsiyet (0-Kadın, 1-Erkek) & & $-0,026$ \\
Yaş & & $-0,023$ \\
Medeni (0-Yalnız, 1-Birlikte) & $-0,102$ & $-0,062$ \\
Çocuk Sayısı & $-0,082$ & $-0,007$ \\
Haftalık çalışma saati & $-0,166^{* *}$ & 0,028 \\
İşükü & $-0,009$ & $0,285^{* *}$ \\
Zaman Baskısı & 0,101 & $0,181^{*}$ \\
İșten aileye & 3,634 & $-0,236^{* *}$ \\
Aileden İşe & 5 & $-0,057$ \\
$F$ & 0,044 & 13,542 \\
$d f$ & & 9 \\
$R^{2}$ & & 0,283 \\
$\Delta \boldsymbol{R}^{2}$ & & $\mathbf{0 , 2 4 5}$ \\
\hline
\end{tabular}


Tablodan görüldüğü üzere, demografik değişken olarak cinsiyet, yaş, medeni durum, çocuk sayısı ve iş ile ilgili olarak haftalık çalışma saati ilk aşamada değerlendirilmiştir. İlk aşamada sadece medeni durum açısından bir etki görülmüştür. Birlikte yaşayanların tükenmişlik düzeylerinin daha düşük olduğu anlaşılmıştır. İkinci aşamada, bu değişkenler kontrol edilmiş; iş yükü, zaman baskısı, işten aileye çatışma öz-yeterliği ve aileden işe çatışma öz-yeterliği değişkenleri analize dahil edilmiştir. Regresyon analizi sonucunda $R^{2}$ değişimi $\Delta R^{2}=0,245$ ( $\left.\mathrm{p}<0,01\right)$ olup, iş yükünün $(\beta=0,285, \mathrm{p}<0,01)$, zaman baskısının $(\beta=0,181, p<0,05)$ beta katsayıları istatistiksel olarak anlamlıdır. Dolayısıyla; H1, H2 hipotezleri doğrulanmıştır. İş ve aile çatışmasını yönetme öz-yeterliği ölçeğinin alt boyutlarıyla ise İAÇY öz-yeterliğinin tükenmişliği yordamakta olduğu saptanırken $(\beta=-0,236, p<0,01)$, aileden işe çatışma boyutunu anlatan AİÇY öz-yeterliği alt boyutunun tükenmişlik üzerinde etkisinin olmadığı gözlenmiştir $(\beta=-0,057, p>0,05)$. Bu durumda H3 hipotezi doğrulanırken, H4 hipotezi doğrulanamamıştır. Regresyon analizinin sonuçlarını yorumlamakgerekirse, işin nicel taleplerinden olan iş yükü ve zaman baskısı boyutlarının tükenmişlik üzerinde pozitif yönde ve anlamlı bir etkiye sahip olduğu görülmektedir. Çalışanların iş yükü ve zaman baskısı arttıkça tükenmişlikleri de artmaktadır. Özellikle modeldeki beta katsayıları incelendiğinde, iş yükünün tükenmişlik üzerinde en güçlü etkiye olan değişken olduğu göze çarpmaktadır. İAÇY öz-yeterliğinin de tükenmişlik üzerinde negatif yönde anlamlı bir etkisi olduğu görülmüștür. Dolayısıyla, bireylerin İAÇY özyeterliği arttıkça tükenmişlikleri azalmaktadır. Aynı sonuçlar AİÇY öz-yeterliğinde de beklenirken, evden işe yönelik çatışmayı yönetme öz-yeterliğinin tükenmişlik üzerinde herhangi bir etkisinin olmaması ilginç bir sonuç olarak karşımıza çımıştır.

Bu bölümün başında belirtildiği gibi, çalışmanın ana varsayımı işin nicel talepleri ile tükenmişlik arasında iş ve aile çatışmasını yönetme öz-yeterliğinin aracılık etkisi olduğudur. Aracıllk etkisinin varlığından söz edebilmek için, üç koşulun yerine gelip gelmediğinin test edilmesi gerekmektedir. Üç koşul şu şekildedir (Baron ve Kenny, 1986: 1144) :

1) Bağımsız değişskenin (nicel talepler), aracı değiş̧ken (İAÇY öz-yeterliği) üzerinde etkisi olmalıdir.

2) Bağımsız değişkenin (nicel talepler), bağımlı değişken (tükenmişlik) üzerinde etkisi olmalidir.

3) Aracı değişkenin (İAÇY öz-yeterliği) bağımlı değişken (tükenmişlik) üzerinde etkisi olmalıdır.

$\mathrm{Bu}$ üç koşulda da ilişkiler anlamlı ise, aracı değişken, ikinci adımdaki regresyon analizine dahil edilmektedir. Eğer bağımsız değişkenle bağımlı değişken arasında anlamlı olmayan bir ilişki çıkarsa, tam aracılık etkisi (full mediation), bağımsız değiş̧ken ile bağımlı değişken arasındaki ilişkide azalma meydana gelirse kısmi aracılık (partial mediation) etkisinden söz edilir (Baron ve Kenny, 1986: 1144; Gürbüz ve Bekmezci, 2012: 200) .

Bu açıklamalar ışığında, temel varsayım iki alt hipotezde toplanabilir:

H5a: İş yükü ile tükenmişlik ilişkisinde İAÇY öz-yeterliğinin aracılık etkisi vardır.

H5b: Zaman baskısı ile tükenmişlik ilişkisinde İAÇY öz-yeterliğinin aracılık etkisi vardır. 
Tablo 5: Aracı Değişken Regresyon Testi Sonuçları

\begin{tabular}{|c|c|c|c|c|c|c|c|}
\hline Denklem & $\begin{array}{l}\text { Bağımsız } \\
\text { Değişken }\end{array}$ & $\begin{array}{l}\text { Bağımlı } \\
\text { Değişsken }\end{array}$ & $b$ & Std. Hata & B & $R^{2}$ & $F$ \\
\hline 1a & İş Yükü & İAÇY Öz-yeterliği & $-0,370$ & 0,099 & $-0,183^{* *}$ & 0,033 & 14,04 \\
\hline $1 b$ & İAÇY Öz-yeterliği & Tükenmişlik & $-0,142$ & 0,027 & $-0,255^{* *}$ & 0,065 & 28.38 \\
\hline $1 c$ & İş Yükü & Tükenmişlik & 0,487 & 0,050 & $0,433^{\star *}$ & 0,187 & 93,74 \\
\hline $1 d$ & $\begin{array}{c}\text { İAÇY Öz-yeterliği } \\
\text { İş Yükü }\end{array}$ & Tükenmişlik & $\begin{array}{r}-0,101 \\
0,450\end{array}$ & $\begin{array}{l}0,025 \\
0,050\end{array}$ & $\begin{array}{l}-0,182^{* *} \\
\mathbf{0 , 3 9 9 *}\end{array}$ & - & 57,04 \\
\hline $2 a$ & Zaman Baskısı & İAÇY Öz-yeterliği & $-0,291$ & 0,094 & $-0,151^{* *}$ & 0.023 & 9,50 \\
\hline $2 b$ & İAÇY Öz-yeterliği & Tükenmişlik & $-0,459$ & 0,086 & $-0,255^{* *}$ & 0.065 & 28,38 \\
\hline $2 c$ & Zaman Baskısı & Tükenmişlik & $-0,478$ & 0,048 & $0,446^{* *}$ & 0,199 & 100,94 \\
\hline $2 \mathrm{~d}$ & $\begin{array}{c}\text { İAÇY Öz-yeterliği } \\
\text { Zaman Baskısı }\end{array}$ & Tükenmişlik & $\begin{array}{r}-0,107 \\
0,446 \\
\end{array}$ & $\begin{array}{l}0,024 \\
0,047\end{array}$ & $\begin{array}{l}-0,192^{* *} \\
\mathbf{0 , 4 1 7 ^ { * * }}\end{array}$ & & 62,32 \\
\hline
\end{tabular}

Not: $\left(^{*}\right) p<0,05,\left(^{* *}\right) p<0,01$

Aracılık etki testinin sonuçlarının yer aldığı tablodaki istatistiklere baktığımızda, ilk olarak, iş yükünün tükenmişlik üzerinde etkisinin olduğunu görmekteyiz $(\beta=0,433, p<0,01)$. İAÇY özyeterliği ise, tükenmişliği negatif şekilde yordamaktadır $(\beta=-0,255, p<0,01)$. İs yükü de İAÇY öz-yeterliği üzerinde ters yönlü bir etkiye sahiptir $(\beta=-0,183)$. Bağımlı değişkenin tükenmişlik olduğu regresyon analizine, İAÇY öz-yeterliğini ilk aşamada analize yerleştirdikten sonra, ikinci aşamada iş yükü ile birlikte İAÇY öz-yeterliği teste tabi tuttuğumuzda ise, iş yükünün tükenmişlik üzerindeki etkisinin anlamlı olmaya devam etmesine rağmen, $\beta$ katsayısının düştüğü görülmüştür $(\beta=0,399, \mathrm{p}<0,01)$. Bu durumda, H5a hipotezindeki aracılık etkisinin tam değil ancak kısmi olduğu söylenebilir. Bir diğer ifadeyle, iş yükü ile tükenmişlik ilişkisinde İAÇY öz-yeterliğinin kısmi aracılık etkisi vardır.

Benzer sonuçlar zaman baskısı ile iş kaynaklı tükenmişlik arasında da bulunmuştur. Zaman baskısı iş kaynaklı tükenmişliği olumlu şekilde yordamaktadır $(\beta=0,446, p<0,01)$. İAÇY özyeterliği ise, tükenmişliği negatif şekilde yordamaktadır $(\beta=-0,255, p<0,01)$. Zaman baskısı da yine 
İAÇY öz-yeterliği üzerinde olumsuz bir etkiye sahiptir $(\beta=-0,151, \mathrm{p}<0,01)$. Bağımlı değişkenin iş kaynaklı tükenmişlik olduğu regresyon analizine, İAÇY öz-yeterliğini ilk aşamada soktuktan sonra, ikinci aşamada zaman baskısı ile birlikte İAÇY öz-yeterliğini teste tabi tuttuğumuzda ise, zaman baskısının iş kaynaklı tükenmişlik üzerindeki etkisinin anlamlı olmaya devam etmesine rağmen, $\beta$ katsayısının düştüğü görülmüştür $(\beta=0,417, p<0,01)$. Bu durumda, H5b hipotezi de kısmi olarak kabul görmüştür. Dolayısıyla, zaman baskısı ile tükenmişlik ilişkisinde İAÇY öz-yeterliğinin kısmi araclık etkisi vardır. Yukarıda yer alan tablonun görsel olarak özeti Şekil l’de incelenebilir.

Şekil I: İşin Nicel Talepleri ile Tükenmişlik İlişkisinde IAÇYÖ’nin Kısmi Aracılık Etkisi

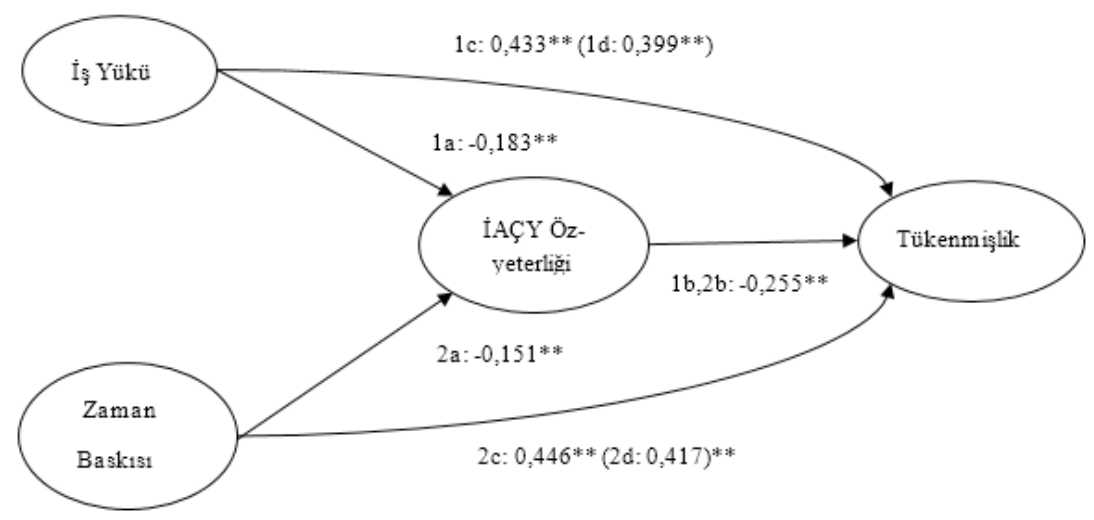

Bu şekli kısaca yorumlamak gerekirse; hem iş yükü hem de zaman baskısı açısından işin nicel talepleri, bireyin işten aileye yönelik çatışmayı yönetme öz-yeterliğini kısmi olarak azaltarak, tükenmişliği arttırmaktadır.

\section{Tartışma}

Çalışanlar, çalışma yaşamında karşılaşıtıkları iş taleplerinin yanında iş dışı yaşamlarında da aile talepleriyle karşılaşırlar. İş talepleri ve aile talepleri arasındaki dengenin sağlanamaması durumunda, iş ile aile arasında çatışma yaşanabilir. Bireyin aile yaşamı talepleri, çalışma yaşamında karşılaşılan iş taleplerini yerine getirmeyi engelliyorsa aile-iş çatışması, çalışma yaşamında karşılaşılan iş talepleri, aile taleplerini yerine getirmeyi engelliyorsa iş-aile çatışması yaşanabilmektedir. Bu araştırmada, iki alanın taleplerinden doğan uyumsuzluğu yönetmeye dair bireyin kendine inancı olan öz-yeterliğinin işin nicel talepleriyle tükenmişlik arasındaki ilişkide aracilık etkisi incelenmiştir. Detaylandırmak gerekirse, termik santral çalışanları üzerinde iş yükü ve zaman baskısının tükenmişliğe etkisinde İAÇY öz - yeterliği ve AİÇY öz-yeterliği aracı değişkeninin rolü araştırılmış ve araştırmada yer alan değişkenler açısından belirleyici faktörlerin etkisi de incelemeye dâhil edilmiştir. 
Çalışmada, regresyon analizi sonuçlarına göre, işin nicel talepleri olan iş yükü ve zaman baskısının tükenmişlik üzerinde anlamlı ve pozitif yönde bir etkiye sahip olduğu saptanmıştır. Kısa zamanda çok iş yetiştirmeye çalışmak, personel yetersizliği, makine ve teçhizattaki teknik aksaklıklar bireyin iş yükünü ve işi yetiştirmeye çalışırken zamansal olarak hissettikleri baskıyı arttırırken, bireylerin işten kaynaklı stres yaşamalarına da neden olmaktadır. Bireyin iş yaşamında karşılaştığı iş yükü, zaman baskısı gibi örgütsel stres kaynakları, bireyde fiziksel ve psikolojik yorgunluk oluşturmakta ve bu durum uzun süre devam ettiğinde tükenmişlik düzeyi artmaktadır. İlgili yazına bakıldığında bu sonucu destekleyen araştırmalarla karşılaşılmıştır (Demerouti vd., 2001; Bakker ve Demerouti, 2007; Schaufeli, 2009).

Öz-yeterlik, bireyin belirli davranışları yerine getirmede kendine olan inancıdır. Öz-yeterlik belirli alanlara özgü değerlendirilebilmekle birlikte bu çalışmada iş ile aile arasında yaşanan çatışmayı yönetmeye ilişkin olarak ele alınmıştır. Örgütsel stres kaynaklarından olan iş yükü ve zaman baskısının bireyin iş ve aile çatışmasını yönetme öz-yeterliğine olumsuz etkisi olduğu görülmektedir. Bir diğer ifadeyle, araştırma sonuçlarına göre, işyerindeki iş yükü ve işi bitirmeye yönelik zaman baskısı arttıkça bireylerin işten aileye çatışma yönetme öz-yeterlikleri düşmektedir. İlgili yazında İAÇY öz-yeterliği ve işin nicel talepleri ilişkisiyle ilgili bir araştırmaya rastlanmamıştır. Fakat iş yükü ve zaman baskısının iş ve aile çatışmasını arttırdığına yönelik (Greenhaus ve Beutell, 1985; Byron, 2005; Keleş-Ay, 2010) çalışmalar mevcuttur.

Araştırma bulgularında, iş talepleri ile tükenmişlik arası ilişkide, İAÇY öz-yeterliğinin kısmi aracılık etkisine sahip olduğu görülmüştür. Bir diğer ifadeyle, işyerinde karşılaşılan iş yükü ve zaman baskısı, bireylerin İAÇY öz-yeterliklerini düşürerek, bireylerin tükenmişlik düzeylerini arttırmaktadır. Benzer şekilde, Peeters vd. (2005), işin nicel talepleri ile tükenmişlik arasındaki ilişkide iş-aile çatışmasının aracılık etkisi olduğunu yüksek iş taleplerinin iş ve aile çatışmasına neden olup tükenmişliği arttırdığını tespit etmişlerdir. Düşük öz-yeterlik algısına sahip olan çalışanların iş kontrol düzeyi düşüklügü sebebiyle daha fazla tükenmişlik yaşamaları mümkündür (Bolat, 2011: 258).

Araştırma bulgularında iş yükü algı düzeyi ile İAÇY öz-yeterliği cinsiyet açısından farklılık göstermiştir. Sayılar arasında dağılımda dengesizlik bulunsa da, kadınlar erkeklerden daha fazla iş yükü hissetmekte ve işten aileye yönelik çatışmayı yönetmede öz-yeterlikleri de düşük seyretmektedir. Geleneksel aile yapısı gereği kadınlar, ev talepleriyle ilgili erkeklerden daha aktif bir rol izlemektedirler. Bu nedenle ev taleplerinin karşılanmasında önemli bir etkiye sahip olan kadınlar, iki alanda sürdürmekte oldukları roller nedeniyle daha fazla yorgunluk yaşayabilmektedirler. Yorgunluğu erkeklerden yüksek hisseden kadınlar, roller arası geçişte zorlanma sebebiyle iş yaşamındaki taleplerle ilgili iş yükünü daha fazla hissetmektedirler. İlgili yazında cinsiyet değişkeniyle iş yükü algısı arasında anlamlı bir fark olmadığı (Keser, 2006: 113; Turgut, 2011: 166), erkeklerin kadınlardan daha fazla iş yükü hissettiği (Kaya, 2016: 41), kadınların erkeklerden daha fazla tükenmişlik hissettiği (Peeters, 2005: 55) gibi sonuçlar bulunmaktadır. Erkeklerin İAÇY öz-yeterliğinin kadınlardan daha yüksek olması ise çalışanların büyük bir çoğunluğunun eşlerinin çalışmıyor olmasından kaynaklanabilmektedir. Ev ve ailenin 
taleplerinin çalışmayan (kadın) eşler tarafından karşılanıyor olması nedeniyle, erkeklerin İAÇY öz-yeterliğinin daha yüksek olması beklenen bir sonuç olmuştur. Ataerkil bir toplumda ev taleplerindeki sorumluluğun kadınların üstünde daha fazla olması ve çalışmayan kadının ev talepleri konusunda fedakârlık gösteren kişi olarak algılanması, kadının görevinin aile ve ev bakımı, erkeğin görevinin ise eve gelir getirme olarak görülmesi bu sonucu açılamaktadır.

$\mathrm{Bu}$ çalışmada bireylerin birlikte yaşadıkça daha az tükenmişlik yaşadıkları yalnız olanların ise tükenmişliğinin daha fazla olduğu sonucuna ulaşılmıştır. Birlikte yaşayanların haftalık çalışma saati yalnız yaşayanların haftalık çalışma saatinden daha düşük gözlemlenmiştir. Yazın açısından kıyas yapıldığında ise medeni durum ve tükenmişlik ilişkisinde birbirinden farklı sonuçlar olduğu görülmüştür. Medeni durum ve tükenmişlik ilişkisinde anlamlı bir farklılık olmadığ (Budak ve Sürgevil-Dalkılıç, 2005: 102), (Mermi, 2015: 59), evli çalışanların bekar çalı̧anlara oranla daha fazla iş-aile çatışması yaşadıkları fakat sosyal destek faktörünün etkisiyle daha az tükenmişlik yaşadıkları (Çoban, 2014: 99), çalışma saati arttıkça iş-aile çatı̧̧ması ve duygusal tükenmişliğin artmakta olduğu (Çoban, 2014: 103) sonuçları bireylerin evliliğe yüklediği anlam, eşin çalışma durumu, eşten alınan sosyal destek, iş bölümünün nasıl yapıldığıyla ilgili olarak sonuçların farklılığı normal bir durum olarak görülmektedir.

Son olarak, araştırmanın kısıtları üzerinde durmak gerekirse, örneklemdeki cinsiyet (\%94,1'i erkek, \%5,9'u kadın) ve meslek sınıflarındaki (\%83,1 mavi yaka, \%16,9 beyaz yaka) dağılımın yakın olmaması bazı bulguları geçerli kılmamızın önünde engel teşkil etmiştir. Ayrıca, örneklemde büyük bir çoğunluğun eşlerinin çalışmıyor olması, aile ve iş çatışmasını yönetme öz-yeterliğinin oluşturacağ 1 etkileri izlememizin önüne geçmiştir. Bu konuda yapılan sonraki araştırmalarda, Karasek Talep-Kontrol modelini daha iyi test etmek üzere, İAÇY ve AİÇY öz-yeterliğinin iş talepleri ile tükenmişlik arasındaki ilişkide düzenleyici rolünün üzerinde durulması önerisinde bulunulabilir.

\section{Sonuç}

İş yükü, zaman baskısı, vardiyalı çalışma, mesai programları gibi psiko-sosyal risk faktörleri, günümüzün önemli stres kaynakları olarak görülmekte ve bu iş talepleri tükenmişlik üzerinde olumsuz bir etki yaratmaktadır. Tüm bu iş talepleri bireyin sadece iş ortamında değil, aynı zamanda özel yaşamında da etkili olmaktadır. Çünkü işletme ve aile, toplumu oluşturan birimler olması gerçeğiyle birbirini etkileyen kavramlardır. Nitekim bireyin genel olarak tükenmişlik içinde bulunması iş ortamındaki psiko-sosyal risklerin, aynı zamanda bireyin özel yaşamını olumsuz etkilemesinden de kaynaklanmaktadır. Bu nedenle, bu çalışmada iş yükü olarak iş taleplerinin yanında, bireyin iş ve özel yaşamı arasındaki dengeyi sağlamaya yönelik özyeterliğinin tükenmişliği etkileyebilecek bir değişken olduğu düşünülmüştür.

Çalışmada, işyerindeki iş yükü ve zaman baskısına ilişkin nicel talepler arttıkça, iş aile çatışmasını yönetmeye ilişkin öz-yeterliğinin düştüğü ve bireyin tükenmişlik düzeyinin arttığı gözlenmiştir. Bir diğer ifadeyle, işin nicel talepleri bireyin işin aileye olan etkilerini yönetmede kendine olan inancında 
düşüş göstererek tükenmişliği olumsuz etkilemektedir. Elde edilen bu sonucu yorumlamak gerekirse, yoğun rekabet ortamında işyerlerinde giderek daha çok ağırlaşan iş taleplerini yerine getirmek durumunda olan çalışanların tükenmişlik yaşaması beklenen bir sonuçtur. İşyerlerinde bireyin kapasitesini fazlasıyla zorlayan iş taleplerine yönelik önlem alınması gerekliliği açıktır. Tükenmişliğe sebep olan, iş yükü ve zaman baskısını önlemek için organizasyonlarda uygun yapılandırmalar yapılmalıdır. İş yükünü fazla hisseden birimlerde planlanan üretim miktarları ve üretim miktarlarına karşılık çalışan kişi sayısı dengesi kontrol edilmeli ve ihtiyaç varsa çalışan sayısı arttırmalıdır. Çalışanları yavaşlatıp iş yükünün artmasına neden olan teknik aksaklıklara anında çözüm üretilmelidir. Çalışanlara düzenli eğitim verilip, iş yükü ile baş etmede becerilerini geliştirmeleri sağlanmalıdır. Çalışanların özellikle iş yükünde yoğunlaşma yaşayacağı dönemler önceden kestirilmeli ve uygun planlamalarla çalışanlara destekler sağlanmalıdır. Vardiya programları ve mesailer hakkında çalışanların özel yaşamlarındaki programlarını düzenleyebilmeleri açısından önceden bildirim yapılmalıdır. Fazla mesai süregelen bir durum olmaktan çıkmalı ve çalışana fazla mesai konusunda yemek, saat ücreti gibi hakları verilmeli ve fazla mesai hakkında çalışanın da fikri alınmalıdır. Ayrıca bireylere mesai konusunda uygun ödül koşulları sağlanırsa, ücretleri hemen yatırılırsa fazla çalışma çalışan için bir yük olmaktan çıkacaktır. Önemli olan çalışanın da iş ve işletme için kendisinin önemli olduğunu fark etmesi ve emeğinin karşılıksız kalmamasıdır. Çalışan ve yönetici arasında açık iletişim kurulmalı ve çalışanların kararlara katılım göstermesi için teşvik edilmesi önemsenmelidir.

Soruna ilişkin alınabilecek bu önlemlerin yanı sıra, bireyin işi ve özel yaşamı arasındaki zamanı yönetmeye ilişkin kendine olan güveni üzerinde durmak da ikinci bir önlem olarak düşünülebilir. $\mathrm{Bu}$ durumda, işyerlerinin, aile dostu işletme modelini benimsemeleri olumlu bir girişim olacaktır. Ayrıca, çalışan yardım programları oluşturulması, iş psikologlarından destek alınması da bu önlemler arasında sayılabilir. Çünkü Karasek’in Talep-Kontrol-Destek modelinden yola çıkıldığında, bireylerin işten kaynaklanan tükenmişliğini gidermede iş taleplerinin olumsuz etkisini azaltmak için destek mekanizmaları ve çalışanın karar alma özgürlüğünün sağlanması önerilebilir. Bu durumda, iş talepleri ile tükenmişlik arasında sıkışan bireyin zaman temelli aile destek politikaları uygulanması gibi bir destek görmesi yaşanılan gerilimi azaltabilecektir. Dolayısıyla, tükenmişliği azaltmak adına iş yerinde bireyin iyilik halini arttırıcı motivasyon uygulamalarına ve bireye iş talepleri ile baş etmeye yardımcı olacak iş kaynaklarına ihtiyaç vardır. Bu durumda, iş stresini arttıran iş talepleri karşısında, örgütler, iş kaynaklarını arttırarak, çalışanların iş taleplerinin bireyde sebep olduğu stresin azalmasına yardımcı olmalıdır.

\section{Kaynakça}

Amanvermez, Y. ve Denizli, S. (2016). İş ve Aile Çatışmasını Yönetme Öz-Yeterliği Ölçeği Türkçe Formunun Uyarlanması: Yapı Geçerliği ve Güvenirlik Çalışması. Ege Eğitim Dergisi, 17(1), 1-17.

Aytaç, Ö. (2002). Boş Zaman Üzerine Kuramsal Yaklaşımlar. Fırat Üniversitesi Sosyal Bilimler Dergisi Cilt, 12, 231-260.

Bakker, A. B., Demerouti, E., ve Euwema, M. C. (2005). Job Resources Buffer The Impact of Job Demands on Burnout. Journal of Occupational Health Psychology, 10(2), 170. 
Bakker, A. B. ve Demerouti, E. (2007). The Job Demands-Resources Model: State of The Art. Journal of Managerial Psychology, 22(3), 312.

Bandura, A. (1977). Self-Efficacy: Toward a Unifying Theory of Behavioral Change. Psychological Review, 84(2), $191-215$.

Baron, R. M. ve Kenny, D. A. (1986). The Moderator-Mediator Variable Distinction in Social Psychological Research: Conceptual, Strategic and Statistical Considerations. Journal of Personality And Social Psychology, 51(6), 1173.

Bolat, O. İ. (2011). İş Yükü, İş Kontrolü ve Tükenmişlik İlişkisi, Atatürk Üniversitesi İktisadi Ve İdari Bilimler Dergisi, 25(2).

Brotheridge, C. M., ve Grandey, A. A. (2002). Emotional Labor and Burnout: Comparing Two Perspectives of "People Work". Journal of Vocational Behavior, 60(1), 17-39.

Bolat, O. İ. (2011). Öz Yeterlilik ve Tükenmişlik İlişkisi: Lider-Üye Etkileşiminin Aracılık Etkisi/The Relationships Between Self-Efficacy and Burnout: Mediating Effects of Leader-Member Exchange. Ege Akademik Bakış, 11(2), 255.

Budak, G. ve Sürgevil-Dalkılıç, O. (2013). Tükenmişlik ve Tükenmişliği Etkileyen Örgütsel Faktörlerin Analizine İlişkin Akademik Personel Üzerine Bir Uygulama. Dokuz Eylül Üniversitesi İktisadi Ve İdari Bilimler Fakültesi Dergisi, 20(2).

Byron, K. (2005). A Meta-Analytic Review of Work-Family Conflict and Its Antecedents. Journal of vocational behavior, 67(2), 169-198.

Ceylan, G. (2011). Aile Dostu Uygulamaların Işs-Özel Yaşam Dengesi Üzerindeki Etkisi (Doctoral Dissertation, DEÜ Sosyal Bilimleri Enstitüsü).Cüceloğlu, D. (2011), İnsan ve Davranışı, Evrim Matbaacılık, İstanbul.

Çoban, H. (2014). Işs - Aile Çatışması ve Tükenmişlik Arasındaki İlişki: Bankacılık Sektöründe Bir Araştırma (Doctoral Dissertation, Pamukkale Üniversitesi).

Dalkılıç-Sürgevil, O. (2014). Çalışma Hayatında Tükenmişlik Sendromu. Nobel Yayınları.

Dalkılıç-Sürgevil, O. (Ed.). (2015). ÇalışAnne-Kadın Akademisyenlerin Kaleminden Çalışma Yaşamında Annelik. Nobel Akademik Yayıncılık. Ankara.

Demerouti, E., Bakker, A. B., Nachreiner, F. ve Schaufeli, W. B. (2001). The Job Demands-Resources Model of Burnout. Journal of Applied Psychology, 86(3), 499.

Demerouti, E., Bakker, A. B. ve Bulters, A. J. (2004). The Loss Spiral of Work Pressure, Work-Home İnterference and Exhaustion: Reciprocal Relations in a Three-Wave Study. Journal of Vocational Behavior, 64(1), 131-149.

Freudenberger, N. J. (1974). Staff Burn-Out. Journal of Social Issues, 30 (1): 159-165.

Gözükara-Yıldız, İ. (2014). İş Gerekleri ve Kaynaklarının Iş-Aile Çatışması Aracıllğı İle İşe Tutkunluk ve Tükenmişlik Üzerindeki Etkisi (Yayınlanmamış Doktora Tezi). İstanbul Arel Üniversitesi Sosyal Bilimler Enstitüsü.

Greenhaus, J. H. ve Beutell, N. J. (1985). Sources of Conflict Between Work and Family Roles. Academy of Management Journal, 10, 76-88.

Greenhaus, J. H., Collins, K. M. ve Shaw, J. D. (2003) The Relation Between Work-Family Balance and Quality of Life, Journal of Vocational Behavior, 63.

Gürbüz, S. ve Bekmezci, M. (2012). İnsan Kaynakları Yönetimi Uygulamalarının Bilgi İşçilerinin İşten Ayrılma Niyetine Etkisinde Duygusal Bağlılığın Aracılık ve Düzenleyicilik Rolü. İstanbul University Journal of the School of Business, 41(2), 189-213. 
Health And Safety Executive. (2010). What Are Psychosocial Risk Factors?, Health And Safety Executive, Http://Www.Hse.Gov.Uk/Msd/Mac/Psychosocial.Htm (Erişim Tarihi: 13.05.2017)

Heerwagen, J., Kelly, K. ve Kampschroer, K. (2006). The Changing Nature of Organizations, Work, And Workplace. Retrieved September, 19, 2006.

Hennessy, K. D. ve Lent, R. W. (2008). Self-Efficacy for Managing Work-Family Conflict: Validating The English Language Version of a Hebrew Scale. Journal of Career Assessment.

Hill, E., Miller, B., Weiner, S. ve Colihan, J. (1998). Influences of the Virtual Office on Aspects of Work and Work/Life Balance. Personnel Psychology, 51, 667-684.

International Labour Organization (2016). “Workplace Stress: A Collective Challenge”. World Day For Safety And Health At Work, 26 April 2016, Geneva.

ILO-UNDP (International Labour Organization-United Nations Development Programme). (2009). Work and Family: Towards New Forms of Reconciliation with Social Co-responsibility. Geneva: ILOUNDP.

ILO, İnsana Yakışır İş, http://www.ilo.org/ankara/areas-of-work/dw/lang-tr/index.htm, (Erişim tarihi: 21.11.2017)

Jackson, S. E. ve Maslach C. (1982). After - Effects Of Job - Related Stress: Families As Victims, Journal Of Occupational Behavior, 3, 63-77.

Kanten, P. (2014). Effect of Quality of Work Life (Qwl) on Proactive And Prosocial Organizational Behaviors: A Research on Health Sector Employees. Suleyman Demirel University Journal of Faculty of Economics \& Administrative Sciences, 19(1).

Kapız-Özen. S. (2002). İş-Aile Yaşamı Dengesi ve Dengeye Yönelik Yeni Bir Yaklaşım: Sınır Teorisi. Dokuz Eylül Üniversitesi Sosyal Bilimler Enstitüsü Dergisi, 4 (3).

Karasek, R. A. (1979). Job Demands, Job Decision Latitude, and Mental Strain: Implications for Job Redesign. Administrative Science Quarterly, 285-308.

Karasek, R. A., Triantis, K. P. ve Chaudhry, S. S. (1982). Coworker and supervisor support as moderators of associations between task characteristics and mental strain. Journal of Occupational Behavior, 3, 181-200.

Kaya, E. (2016). İş Talepleri ve İş Kaynaklarının İşe Tutkunluğa Etkisinde Pozitif Psikolojik Sermayenin Aracılık Rolünün İncelenmesi. Maltepe Üniversitesi Yüksek Lisans Tezi, İstanbul.

Keser, A. (2006). Çağrı Merkezi Çalışanlarında İş Yükü Düzeyi ile İş Doyumu İlişkisinin Araştırılması. Kocaeli Üniversitesi Sosyal Bilimler Enstitüsü Dergisi, 11(1), 100-119.

Keser, A., ve Kümbül-Güler, B. (2016). Çalışma Psikolojisi. Umuttepe Yayınları, Kocaeli.

Kristensen, T. S., Borritz, M., Villadsen, E. ve Christensen, K. B. (2005). The Copenhagen Burnout Inventory: A New Tool For the Assessment of Burnout. Work \& Stress, 19(3), 192-207.

Kristensen, T. S. (2010). A Questionnaire Is More Than A Questionnaire. Scandinavian Journal of Public Health, 38(3), 149-155.

Kula, S. (2011). Occupational Stress and Work-Related Wellbeing of Turkish National Police (Tnp) Members. The University of Central Florida, Doctoral Dissertation.

Leiter, M. P. ve Maslach, C. (2000). Burnout And Health. Handbook of Health Psychology, 415-426.

Leka, S., ve Cox, T. (2010). Psychosocial Risk Management at the Workplace Level. (İçinde) S. Leka \& J. Houdmont (Edi.), Occupational Health Psychology (ss: 124-156). Wiley Blackwell.

Lerman, Y., Finkelstein, A., Levo, Y., Tupilsky, M., Baratz, M., Solomon, A., \& Sackstein, G. (1990). Asbestos related health hazards among power plant workers. British journal of industrial medicine, 47(4), 281. 
Malach-Pines, A., ve Yafe-Yanai, O. (2001). Unconscious Determinants of Career Choice and Burnout: Theoretical Model and Counseling Strategy. Journal of Employment Counseling, 38(4), 170-184.

Maslach, C. ve Jackson, S. E. (1981). The Measurement of Experienced Burnout. Journal of Organizational Behavior, 2(2), 99-113.

Mermi, F. Ö. (2015). Öğretmenlerin Mizah Tarzları İle Mesleki Tükenmişlikleri Arasındaki İlişki. Zirve Üniversitesi. Kahramanmaraş Sütçü İmam Üniversitesi Yüksek Lisans Tezi, Gaziantep.

Naktiyok, A. ve Kaygın, E. (2012). Tükenmişlik ve İş Tatmini Düzeylerini Belirlemeye Yönelik Akademik Personel Üzerinde Bir Uygulama. Sosyal ve Beşeri Bilimler Dergisi, 4(1).

Peeters, M. C., Montgomery, A. J., Bakker, A. B. ve Schaufeli, W. B. (2005). Balancing Work and Home: How Job and Home Demands Are Related to Burnout. International Journal of Stress Management, 12(1), 43.

Schaufeli, W. B., ve Bakker, A. B. (2004). Job demands, job resources, and their relationship with burnout and engagement: A multi-sample study. Journal of Organizational Behavior, 25(3), 293-315.

Schaufeli, W. B., Bakker, A. B., ve Van Rhenen, W. (2009). How Changes in Job Demands and Resources Predict Burnout, Work Engagement, and Sickness Absenteeism. Journal of Organizational Behavior, 30(7), 893-917.

Spychala, A. (2009). Proactive Work Behaviour (Doctoral Dissertation).

Şahan, C. (2016) Kopenhag Psiko-sosyal Risk Değerlendirme Ölçeğinin Türkçeye Uyarlanması. Dokuz Eylül Üniversitesi, Sağlık Bilimleri Enstitüsü Halk Sağlığı Anabilim Dalı Yüksek Lisans Tezi.

Turgut, T. (2011). Çalışmaya Tutkunluk: İş Yükü, Esnek Çalışma Saatleri, Yönetici Desteği ve İş-Aile Çatışması İle İlişkileri. Atatürk Üniversitesi İktisadi ve İdari Bilimler Dergisi, 25(3-4).

Vatansever Ç. (2014). Risk Değerlendirme'de Yeni Bir Boyut: Psikososyal Tehlike ve Riskler. Çalışma ve Toplum Dergisi, 1, 117-138

Veldhoven, V. M. (2014). Quantitative Job Demands. An Introduction to Contemporary Work Psychology, 117-143.

Voydanoff, P. (2004). The Effects of Work Demands and Resources on Work-to-Family Conflict and Facilitation. Journal of Marriage and Family, 66(2), 398-412.

Voydanoff, P. (2005). Toward a Conceptualization of Perceived Work-Family Fit And Balance: A Demands and Resources Approach. Journal of Marriage and Family, 67(4), 822-836.

Xanthopoulou, D., Bakker, A. B., Demerouti, E. ve Schaufeli, W. B. (2007). The Role Of Personal Resources in The Job Demands-Resources Model. International Journal of Stress Management, 14(2), 121-141.

Yeh, W. Y., Cheng, Y., Chen, C. J., Hu, P. Y., \& Kristensen, T. S. (2007). Psychometric Properties of the Chinese Version of Copenhagen Burnout İnventory Among Employees in Two Companies in Taiwan. International Journal of Behavioral Medicine, 14(3), 126-133.

Yu, S., Gu, G., Zhou, W., \& Wang, S. (2008). Psychosocial work environment and well-being: a crosssectional study at a thermal power plant in China. Journal of occupational health, 50(2), 155-162. 